\title{
INSIDER OWNERSHIP, FREE CASH FLOW, DAN PERTUMBUHAN TERHADAP DIVIDEND PAYOUT RATIO
}

\author{
Yessri Meiliyawati \\ yessrimeiliyawati95@gmail.com \\ Ellen Rusliati \\ Universitas Pasundan \\ Jl. Tamansari No. 6-8, Bandung 40116
}

diterima: 20/12/2019; direvisi: 26/1/2020; disetujui: 28/4/2020

\begin{abstract}
Dividend alongside capital gain is a return for stock holder. The aim of this study is to determine the condition of insider ownership, free cash flow, growth and dividend payout ratio, and to determine their effect of insider ownership, free cash flow and growth simultaneously and partially on dividend payout ratio. The population were mining companies sector listed in Indonesia Stock Exchange in the period of 2010-2017. The sample of this study is amounted to 4 companies with the amount of observations were 32. The method used were descriptive and verificative using panel data regression. The results showed that simultaneously insider ownership, free cash flow and growth has significant effect on dividend payout ratio with contribution of effect $68.19 \%$. Partially, insider ownership has a significant positive effect, free cash flow and growth have significant negative effect on dividend payout ratio.
\end{abstract}

Keywords: insider ownership; free cash flow; growth; dividend payout ratio; mining companies

\begin{abstract}
Abstrak
Dividen adalah balas jasa kepada para pemegang saham di samping capital gain. Penelitian ini bertujuan untuk mengetahui kondisi insider ownership, free cash flow, growth, dividend payout ratio serta mengetahui besarnya pengaruh insider ownership, free cash flow dan growth terhadap dividend payout ratio secara simultan dan parsial. Populasi sebanyak 45 perusahaan sektor industri pertambangan yang terdaftar di Bursa Efek Indonesia tahun 2010-2017 dengan sampel sebanyak 4 dengan jumlah observasi 32. Metode yang digunakan adalah deskriptif dan verifikatif dengan analisis regresi data panel. Hasil penelitian menunjukkan bahwa insider ownership, free cash flow dan growth berpengaruh positif dan signifikan terhadap dividend payout ratio dengan kontribusi pengaruh sebesar $68,19 \%$. Insider ownership berpengaruh positif signifikan, sedangkan free cash flow dan growth berpengaruh negatif signifikan terhadap dividend payout ratio.
\end{abstract}

Kata Kunci: insider ownership; free cash flow; pertumbuhan; dividend payout ratio; perusahaan pertambangan 


\section{PENDAHULUAN}

Dividen merupakan indikator harga saham dan harga saham adalah indikator nilai perusahaan untuk maksimasi kesejahteraan pemegang saham. Pemegang saham mengharapkan kombinasi tertinggi dividen dan peningkatan harga saham (Yee, 2017). Dividen adalah pembagian laba kepada pemegang saham berdasarkan banyaknya saham yang dimiliki. Dividen berarti keuntungan atau pengembalian atas investasi pemegang saham (Khan, et. al. 2015).

Pembagian ini akan mengurangi laba ditahan dan kas yang tersedia bagi perusahaan, tetapi distribusi keuntungan kepada para pemilik memang adalah tujuan utama suatu bisnis (market.bisnis.com, diakses pada 1 Desember 2018). Dividen pada umumnya dibagikan setahun sekali. Namun, ada kalanya perusahaan tidak membagikan dividen, karena dana diinvestasikan untuk modal kerja atau biasa disebut laba ditahan. Perusahaan juga tidak membagikan dividen jika di akhir periode justru merugi.

Dividend payout ratio (DPR) merupakan rasio yang mengukur besarnya bagian laba bersih setelah pajak yang dibayarkan sebagai dividen kepada pemegang saham (Gitman, L. J. and Zutter, 2015). Besarnya persentase DPR dapat dihasilkan dengan membagi jumlah dividen yang dibagikan dengan laba bersih, dapat juga dengan membagi dividen per lembar saham (dividend per share) dengan laba per lembar saham (earning per share). DPR menunjukkan besaran atau persentase dividen yang dibagikan dari laba bersih setelah pajak serta menunjukkan besaran laba ditahan yang akan digunakan untuk kebutuhan investasi.

Penelitian ini dilakukan pada perusahaan sektor pertambangan yang terdaftar di Bursa Efek Indonesia (BEI). Industri pertambangan merupakan salah satu sektor industri yang memiliki kontribusi besar bagi Indonesia dan pasar modal mulai dari peningkatan pendapatan ekspor, pembangunan daerah, peningkatan aktivitas ekonomi. Potensi yang kaya akan sumber daya alam dapat menumbuhkan terbukanya perusahaanperusahaan untuk melakukan eksplorasi pertambangan sumber daya. Industri pertambangan memerlukan investasi sangat besar, jangka panjang, risiko dan ketidakpastian tinggi sehingga pendanaan menjadi isu utama terkait dengan pengembangan perusahaan. Potensi yang kaya akan sumber daya alam ternyata tidak diimbangi dengan meningkatnya dividen selama lima tahun periode penelitian, dari 47 emiten yang berada di sektor pertambangan hanya 7 yang rutin membagikan dividen secara rutin selama 8 tahun (periode penelitian 2010-2017). Hal ini dapat disebabkan karena beberapa emiten lebih memilih menahan labanya untuk digunakan investasi masa datang dibandingkan melakukan pembagian dividen.

Kebijakan dividen dapat dipengaruhi oleh beberapa faktor diantaranya legal constraints, contractual constraints, growth prospects, owner considerations, dan market considerations (Gitman, and Zutter, 2015). Kebijakan dividen juga dapat dipengaruhi oleh faktor lain seperti posisi solvabilitas, likuiditas, kebutuhan untuk melunasi utang, rencana perluasan, stabilitas pendapatan, dan pengawasan terhadap perusahaan (Sutrisno, 2012), dividen sebelumnya, return on equity, market to book value ratio, dan ukuran perusahaan/ market capitalization (Bostanci, et. al., 2018), free cash flow, pertumbuhan, dan risiko (Hellström \& Inagambaev, 2012), pajak (Rafique, 2012), arus kas operasi (Rehman \& Takumi, 2012), profitabilitas (Kaźmierska-Jóźwiak, 2015), jenis audit (Khan \& Ahmad, 2016), banyaknya direksi dan direksi independen (Nuhu, 2014), peluang investasi (Mui \& Mustapha, 2016).

Insider ownership adalah kepemilikan saham oleh pihak manajemen, pemilik sekaligus pengelola suatu perusahaan yang memiliki kesempatan untuk terlibat langsung dalam pengambilan keputusan dengan memperoleh akses langsung berupa informasi yang ada di dalam perusahaan (Gitman, and Zutter, 2015). Kepemilikan manajerial akan mengefektifkan pengawasan terhadap kegiatan di dalam perusahaan (Dhuhri \& Diantimala, 2018).

Kepemilikan manajerial berhubungan dengan faktor pengawasan terhadap perusahaan dan pertimbangan kepemilikan (owner considerations). Masalah keagenan terjadi karena pemegang saham dengan para manajer memiliki keinginannya dan kepentingannya sendiri. Pembayaran dividen dilakukan untuk mengurangi masalah keagenan antara manajer dan pemegang saham (Baker \& Weigand, 2015).

Free cash flow merupakan kas yang tersedia di perusahaan untuk digunakan berbagai aktivitas. Konsep free cash flow memfokuskan pada kas yang dihasilkan dari aktivitas operasi setelah digunakan untuk kebutuhan reinvestasi (Muhardi, 2013). Semakin tinggi dan stabil keuntungan perusahaan cenderung menghasilkan arus kas bebas lebih tinggi, sehingga dapat meningkatkan meningkatkan DPR (Franc-Dąbrowska, et. al., 2020).

Semakin tinggi arus kas bebas perusahaan maka semakin besar kas yang tersedia dan siap untuk dibagikan kepada pemegang saham setelah perusahaan melakukan investasi dalam aset tetap, produk baru, dan modal kerja yang diperlukan untuk pertumbuhan. Perusahaan besar cenderung mendistribusikan dividen tinggi untuk mempertahankan reputasi di kalangan investor, sementara perusahaan kecil akan mengalokasikan pendapatan mereka ke laba ditahan, sehingga cenderung mendistribusikan dividen yang lebih rendah.

Semakin tinggi tingkat pertumbuhan perusahaan maka semakin semakin kecil kesempatan perusahaan untuk membayar dividen. Hal tersebut terjadi karena perusahaan yang memiliki tingkat pertumbuhan tinggi cenderung lebih senang menahan keuntungannya untuk membiayai pertumbuhan dari pada membaginya sebagai dividen. 
Tingkat pertumbuhan perusahaan dapat diketahui melalui rasio pertumbuhan, dalam penelitian ini rasio yang dijadikan proksi adalah pertumbuhan aset (Kartika, et. al. 2015). Rasio pertumbuhan bertujuan mengukur kemampuan perusahaan dalam mempertahankan kedudukannya dalam pertumbuhan perekonomian dan industri (Jumingan, 2011). Rasio pertumbuhan pada dasarnya terdiri dari dua macam rasio, yaitu: rasio pertumbuhan aset (assets growth) dan rasio pertumbuhan penjualan (sales growth). Dengan pendekatan pertumbuhan penjualan menunjukkan pengaruh yang negatif dan signifikan terhadap DPR (Boban, 2011).

Perumusan masalah dalam penelitian ini adalah: (1) Bagaimana kondisi insider ownership, free cash flow, pertumbuhan dan dividend payout ratio, (2) Seberapa besar pengaruh insider ownership, free cash flow, dan pertumbuhan secara simultan dan parsial terhadap dividend payout ratio pada perusahaan sektor industri pertambangan yang terdaftar di Bursa Efek Indonesia (BEI) periode 2010-2017.

Teori agensi merupakan teori yang memberikan penjelasan agency relationship dengan masalah-masalah yang ditimbulkan (Jensen dan Meckling 1976, dalam (Arifin dan Asyik, 2016). Permasalahan keagenan dapat timbul karena perbedaan kepentingan antara pemegang saham dan agent disebut sebagai pihak manajer perusahaan yang mengelola perusahaan. Masalah keagenan dapat diminimalisir dengan meningkatkan kepemilikan manajerial dalam suatu perusahaan.

Kepemilikan manajerial memberikan kesempatan pada manajer untuk terlibat dalam kepemilikan saham demi menyetarakan kepemilikannya dengan pemegang saham. Semakin besar keterlibatan manajer dalam kepemilikan manajer memberikan tanggung jawab kepada manajer untuk menghasilkan kinerja yang baik bagi perusahaan. kinerja perusahaan yang baik berdampak pada dividen yang akan diterima oleh pemegang saham (Fadhilturrochmah dan Subardjo, 2017).

Hasil penelitian (Supriyanah \& Ghoniyah, 2015), (Iswahyuni, 2018) menyatakan bahwa insider ownership berpengaruh positif dan signifikan terhadap kebijakan dividen pada perusahaan yang terdaftar di Bursa Efek Indonesia. Semakin tinggi insider ownership akan semakin tinggi pula dividen yang dibayarkan kepada investor. Sebaliknya, hasil penelitian (Rahayu \& Rusliati, 2019) menunjukkan pengaruh yang negatif.

Arus kas bebas adalah kas yang tersedia dalam perusahaan setelah melakukan keseluruhan kegiatan operasional dan investasi. Ketersediaan kas yang lebih banyak dapat dimanfaatkan sebagai laba ditahan atau dibagikan kepada pemegang saham sebagai dividen. Arus kas bebas yang tinggi maka semakin tinggi DPR. Hal ini berarti semakin tinggi arus kas bebas yang tersedia dalam suatu perusahaan, maka semakin sehat perusahaan tersebut karena memiliki kas yang tersedia untuk pembayaran dividen (Fadhilturrochmah dan Subardjo, 2017).

Hasil penelitian yang dilakukan oleh (Akhyar, et. al., 2014), (Lucynda, 2012), dan (Fadhilturrochmah dan Subardjo, 2017) menyatakan bahwa free cash flow berpengaruh positif dan signifikan terhadap dividend payout rasio. Semakin besar free cash flow yang tersedia, maka semakin sehat perusahaan tersebut karena memiliki kas yang tersedia untuk pertumbuhan, pembayaran hutang, dan dividen. Jadi, semakin tinggi free cash flow perusahaan semakin tinggi pula dividen yang dibayarkan perusahaan, karena perusahaan memiliki cukup kas yang tersedia.

Pertumbuhan perusahaan dapat dilihat dari pertumbuhan aset yang naik dan turun berdampak pada dividen yang dibagikan kepada pemegang saham. pertumbuhan perusahaan dapat diwujudkan dengan menggunakan investasi dengan sebaik-baiknya. Perusahaan yang memiliki pertumbuhan tinggi akan membutuhkan dana yang besar hal ini memungkinkan untuk menggunakan sebagian besar laba sebagai laba ditahan guna pembiayaan investasi.

Penelitian yang dilakukan oleh (Pambayun \& Sulasmiyati, 2017), (Kartika, et. al. 2015), (Demirgüneş, 2015), dan (Mufidah, 2018) yang menyatakan bahwa pertumbuhan aset berpengaruh signifikan negatif terhadap kebijakan dividen. Semakin tinggi tingkat pertumbuhan maka akan semakin rendah perusahaan membayar dividen. Hipotesis dalam penelitian ini adalah terdapat pengaruh insider ownership, free cash flow, dan growth terhadap dividend payout ratio secara simultan dan parsial.

\section{METODE}

Metode yang digunakan adalah deskriptif dan verifikatif. Operasionalisasi variabel ditunjukkan pada Tabel 1. Populasi adalah perusahaan sektor industri pertambangan yang terdaftar di Bursa Efek Indonesia selama periode 2010-2017. Teknik pengambilan sampel adalah purposive sampling, dengan kriteria perusahaan yang terdaftar di BEI, mempublikasikan laporan keuangan, membagikan dividen, serta memiliki kepemilikan manajerial selama periode penelitian. Sampel berjumlah 4 perusahaan dengan jumlah observasi sebanyak 32 data.

Teknik pengumpulan data yang dilakukan adalah studi kepustakaan, observasi tidak langsung serta dokumentasi. Analisis deskriptif menggunakan nilai rata-rata, nilai maksimum, dan minimum. Analisis verifikatif menggunakan analisis data panel dengan Microsoft Excel, SPSS, dan Eviews 9, dengan didahului dengan uji asumsi klasik. Data diperoleh dari laporan keuangan perusahaan sektor industri pertambangan yang terdaftar di Bursa Efek Indonesia periode 20102017, dengan mengakses www.idx.co.id dan www. sahamoke.com. 


\section{HASIL}

Kondisi insider ownership pada perusahaan sektor industri pertambangan yang terdaftar di BEI periode 2010-2017 mengalami fluktuasi dan cenderung menurun (Gambar 1). Demikian pula halnya dengan kondisi free cash flow (Gambar 2) dan pertumbuhan aset (Gambar 3), sedangkan kondisi DPR berfluktuasi dan cenderung meningkat (Gambar 4).

Hasil uji asumsi klasik menunjukkan data memiliki distribusi normal, tidak terjadi multikolinieritas, dan heteroskedastisitas. Hasil analisis regresi data panel ditunjukkan pada Tabel 2. Insider ownership, free cash flow, dan pertumbuhan berpengaruh sebesar 63,79\% terhadap DPR (Tabel 3). Koefisien determinasi parsial adalah (1) Kontribusi pengaruh insider ownership sebesar $0,99025 \times 0,688659 \times 100 \%=0,6819 \rightarrow 68,19$ $\%$, (2) Kontribusi pengaruh free cash flow sebesar $-0,47208 \times 0,280675 \times 100 \%=-0,1325 \rightarrow-13,25 \%$, (3) Kontribusi pengaruh pertumbuhan terhadap sebesar $-0,286263 \times-0,33937 \times 100 \%=0,0885 \rightarrow 8,85 \%$.

\section{PEMBAHASAN}

Rata-rata kepemilikan manajerial cenderung menurun yang dapat berdampak tidak baik bagi perusahaan karena dapat menimbulkan masalah keagenan yaitu masalah yang terjadi karena memiliki perbedaan kepentingan pihak manajemen dan pemilik perusahaan. Kepemilikan manajerial memberikan kesempatan bagi manajemen untuk terlibat dalam kepemilikan saham dan dapat menyetarakan dengan pemegang saham. Pihak manajemen yang memiliki saham manajerial diharapkan mampu memberikan kinerja yang baik bagi perusahaan, tidak mengutamakan kepentingan masingmasing dan berusaha memakmurkan pemegang saham.

Rendahnya free cash flow menunjukkan bahwa perusahaan cenderung menggunakan sebagian besar kasnya untuk investasi. Rendahnya free cash flow atau arus kas bebas dapat mengakibatkan perusahaan tidak dapat membayar dividen, melunasi utang dan tidak dapat melakukan ekspansi usahanya karena keterbatasan dana.

Kondisi pertumbuhan yang cenderung menurun dapat menunjukkan bahwa perusahaan memiliki pertumbuhan yang tidak baik sehingga dapat menumbuhkan ketidakpercayaan investor.

Kondisi DPR yang cenderung meningkat menunjukkan bahwa perusahaan lebih banyak menggunakan laba bersih sebagai dividen. Peningkatan DPR dapat disebabkan oleh laba bersih mengalami pertumbuhan atau tidak menggunakan laba untuk membiayai investasi di masa datang. Kondisi meningkatnya DPR berdampak baik karena dapat memunculkan anggapan bahwa perusahaan memiliki kinerja yang baik dan dapat memberikan keuntungan yang diharapkan. DPR yang meningkat dapat mencerminkan bahwa perusahaan mampu memakmurkan pemegang sahamnya.

Insider ownership berpengaruh positif terhadap DPR. Insider ownership yang tinggi tidak mencerminkan kecilnya masalah keagenan dalam perusahaan tetapi mengindikasikan bahwa masalah keagenan yang terjadi pada objek penelitian berkaitan dengan struktur kepemilikan yaitu kondisi kepemilikan di Indonesia yang relatif terkonsentrasi dan termasuk perusahaan keluarga. Insider ownership dalam penelitian adalah termasuk pemegang saham kendali. Tingginya insider ownership mengindikasikan agency cost yang tinggi menggambarkan konflik keagenan yang terjadi di antara pemegang saham mayoritas dan minoritas sehingga konsekuensinya perusahaan membayarkan dividen yang lebih tinggi

Penelitian ini sejalan dengan (Supriyanah \& Ghoniyah, 2015) bahwa kepemilikan manajerial (insider ownership) berpengaruh positif terhadap DPR. Selanjutnya penelitian (Iswahyuni, 2018) me nunjukkan kepemilikan manajerial berpengaruh signifikan terhadap kebijakan dividen. Hal ini terjadi akibat komisaris dan direksi yang berperan aktif dalam pengambilan keputusan mendapatkan kesetaraan dengan pemegang saham lainnya yang cenderung membayarakan dividen tinggi.

Free cash flow berpengaruh negatif terhadap DPR. Semakin tinggi free cash flow semakin rendah DPR. Manajemen cenderung menggunakan free cash flow sebagai dana investasi guna pertumbuhan perusahaan (Harun \& Jeandry, 2018). Hal ini sesuai dengan agency theory bahwa manajer yang memiliki aliran kas bebas besar cenderung melakukan investasi secara berlebihan daripada membayarkannya sebagai dividen (Mardiyati, et. al., 2014). Hasil penelitian ini tidak sejalan dengan penelitian (Lucynda, 2012), (Hellström \& Inagambaev, 2012), dan (Akhyar, et. al., 2014) bahwa free cash flow berpengaruh positif terhadap dividend payout ratio.

Pertumbuhan berpengaruh negatif terhadap DPR. Pertumbuhan total aset semakin besar, maka perusahaan akan lebih memilih menggunakan laba yang diperoleh untuk membiayai ekspansi dari pada menggunakannya untuk membayar dividen. Pertumbuhan yang tinggi membuat perusahaan menggunakan sebagian besar laba untuk membiayai pertumbuhan, sehingga laba yang tersisa untuk dibagikan sebagai dividen kepada para pemegang saham akan semakin kecil (Mufidah, 2018), (Demirgüneş, 2015), dan (Hellström \& Inagambaev, 2012).

Hasil penelitian ini sesuai dengan teori maturity hypothesis bahwa, pembayaran dividen mengindikasikan bahwa perusahaan besar dan memiliki tingkat pertumbuhan yang rendah (Suhadak dan Darmawan, 2011). Berdasarkan teori tersebut, semakin tinggi tingkat pertumbuhan perusahaan maka akan semakin rendah kemampuan perusahaan dalam membayar dividen. 
Hal ini sejalan dengan penelitian yang dilakukan oleh (Pambayun \& Sulasmiyati, 2017), (Kartika, et. al. 2015), (Demirgüneş, 2015), (Khan \& Ahmad, 2016), dan (Mufidah, 2018). Hal ini mengindikasikan bahwa semakin tinggi pertumbuhan aset akan menyebabkan menurunnya DPR. Perusahaan yang mempunyai peningkatan aset berarti memiliki tingkat pertumbuhan yang baik dengan menggunakan sumber dana dari laba ditahan, namun bertentangan dengan signaling theory yang menyatakan bahwa pertumbuhan tinggi memberikan kontribusi terhadap dividen lebih tinggi (Hellström \& Inagambaev, 2012).

\section{KESIMPULAN}

Insider ownership, free cash flow, dan pertumbuhan pada perusahaan sektor industri pertambangan yang terdaftar di BEI periode 2010-2017 mengalami fluktuasi dan cenderung menurun. DPR berfluktuasi dan cenderung meningkat. Insider ownership, free cash flow dan pertumbuhan berpengaruh signifikan baik secara simultan maupun parsial terhadap dividend payout ratio. Insider ownership memiliki pengaruh positif dan paling besar.

\section{DAFTAR PUSTAKA}

Akhyar, M., Gunawan, B., \& Candrasari, R. 2014. Pengaruh profitabilitas, leverage, growth, dan free cash flow terhadap dividend payout ratio perusahaan dengan mempertimbangkan corporate governance sebagai variabel intervening. Jurnal Akuntansi \& Auditing Indonesia, 18(2), 89-100. https://doi. org/10.20885/jaai.vol18.iss2.art1

Arifin, S. \& Asyik, N. F. 2016. Pengaruh Profitabilitas, Likuiditas, Growth Potential, dan Kepemilikan Manajerial terhadap Kebijakan Dividen. Jurnal Ilmu Dan Riset Akuntansi, 4(2).

Baker, H. K., \& Weigand, R. 2015. Corporate dividend policy revisited. Managerial Finance, 41(2), 126144. https://doi.org/10.1108/MF-03-2014-0077

Boban, I. 2011. Determinants of Dividend Payout Ratio : Evidence From the Uk. 1-38.

Bostanci, F., Kadioglu, E., \& Sayilgan, G. 2018. Determinants of Dividend Payout Decisions: A Dynamic Panel Data Analysis of Turkish Stock Market. International Journal of Financial Studies, 6(4), 93. https://doi.org/10.3390/ijfs6040093

Brigham, E. F., \& Houston, J. F. 2019. Fundamentals of Financial Management 15 Edition. Cengage Learning.

Demirgüneş, K. 2015. Determinants of target dividend payout ratio: A panel autoregressive distributed lag analysis. International Journal of Economics and Financial Issues, 5(2), 418-426.

Dhuhri, R., \& Diantimala, Y. 2018. International Journal of Social Science and Economic Research
The Influence Of Institutional Ownership, Individual Ownership, And Managerial Ownership Toward Dividend Payout Ratio At Non-Financial Companies Registered In Indonesia Stock Exchange In 2012. 03, 786-801.

Fadhilturrochmah, A. dan Subardjo, A. 2017. Pengaruh Kepemilikan Manajerial, Free Cash Flow dan Investment Opportunity Set terhadap DPR. Jurnal Ilmu Dan Riset Akuntansi, 6(7). jurnalmahasiwa. stiesia.ac.id

Franc-Dąbrowska, J., Mądra-Sawicka, M., \& Ulrichs, M. 2020. Determinants of dividend payout decisionsthe case of publicly quoted food industry enterprises operating in emerging markets. Economic ResearchEkonomska Istrazivanja , 33(1), 1108-1129. https:// doi.org/10.1080/1331677X.2019.1631201

Gitman, L. J. and Zutter, C. J. 2015. Principle of Management Finance (Fourteen). Pearson Education Limited.

Harun, S., \& Jeandry, G. 2018. Pengaruh Profitabilitas, Free Cash Flow, Leverage, Likuiditas Dan Size terhadap Dividen Payout Ratio (DPR) pada Perusahaan Manufaktur yang terdaftar di Bursa Efek Indonesia. Jurnal Riset Akuntansi, 5(2), 122-137.

Hellström, G., \& Inagambaev, G. 2012. Determinants of Dividend Payout Ratios: A Study of Swedish Large and Medium Caps. The Journal of Risk Finance, 7(2), 136-145.

Iswahyuni, S. 2018. Pengaruh Profitabilitas, Pertumbuhan Perusahaan, Kepemilikan Manajerial, Leverage, Likuiditas, Dan Ukuran Perusahaan Terhadap Kebijakan Dividen (Studi Empiris Pada Perusahaan Pertambangan dan Pertanian yang Terdaftar di Bursa Efek Indonesia Tahun 2013201. Jom Fekom, 5(1), 1-15.

Jumingan. 2011. Analisis Laporan Keuangan. Bumi Aksara.

Kartika, A. V., Topowijoyo, dan Endang, M. G. W. 2015. Pengaruh Return On Assets, Return On Equity Dan Assets Growth Terhadap Dividend Payout Ratio (Studi pada Perusahaan Manufaktur yang Terdaftar di Bursa Efek Indonesia Periode 20102012). Jurnal Administrasi Bisnis S1 Universitas Brawijaya, 18(2), 85413.

Kaźmierska-Jóźwiak, B. 2015. Determinants of Dividend Policy: Evidence from Polish Listed Companies. Procedia Economics and Finance, 23(October 2014), 473-477. https://doi.org/10.1016/s22125671(15)00490-6

Khan, S., Anuar, M. A., Ramakrishnan, S., Malik, M. F. 2015. a Study on the Effect of Dividend Payout Ratio and Firm Profitability. Science International (Lahore), 27(2), 1403-1406.

Khan, F. A., \& Ahmad, N. 2016. Determinants of dividend payout: An empirical study of pharmaceutical companies of Pakistan stock exchange (PSE). Proceedings of the 28th 
International Business Information Management Association Conference - Vision 2020: Innovation Management, Development Sustainability, and Competitive Economic Growth, 2017, 869-888. https://doi.org/10.5171/2017.538821

Lucynda, J. dan L. 2012. Pengaruh Free Cash Flow Dan Struktur Kempemilikan Terhadap Dividend Payout Ratio. Jurnal Dinamika Akuntansi, 4(2), 129-138. https://doi.org/10.15294/jda.v4i2.2171

Mardiyati, U., Nusrati, D., \& Hamidah. 2014. Pengaruh Free Cash Flow, Return on Assets, Total Assets Turnover Dan Sales Growth Terhadap Dividend Payout Ratio (Studi Pada Perusahaan Manufaktur Yang Terdaftar Di Bursa Efek Indonesia Periode 2008-2012). Jurnal Riset Manajemen Sains Indonesia (JRMSI), 5(2), 204-221. http://journal. unj.ac.id/unj/index.php/jrmsi/article/view/802/708

Mufidah, M. 2018. Pengaruh Asset Growth, Sales Growth, Net Profit Margin, Current Ratio dan Debt To Equity Ratio terhadap Dividend Payout Ratio pada Perusahaan yang Termasuk dalam Indeks Lq 45 Tahun 2013 - 2016. J-MAS (Jurnal Manajemen Dan Sains), 3(1), 12. https://doi.org/10.33087/jmas. v3i1.39

Muhardi, W. R. 2013. Analisis Laporan Keuangan, Proyeksi, dan Valuasi Saham. Salemba Empat.

Mui, Y. T., \& Mustapha, M. 2016. Determinants of Dividend Payout Ratio: Evidence from Malaysian Public Listed Firms. Journal of Applied Environmental and Biological Sciences, 6(1), 48-54.

Nuhu, E. 2014. Revisiting the Determinants of Dividend Payout Ratios in Ghana. International Journal of

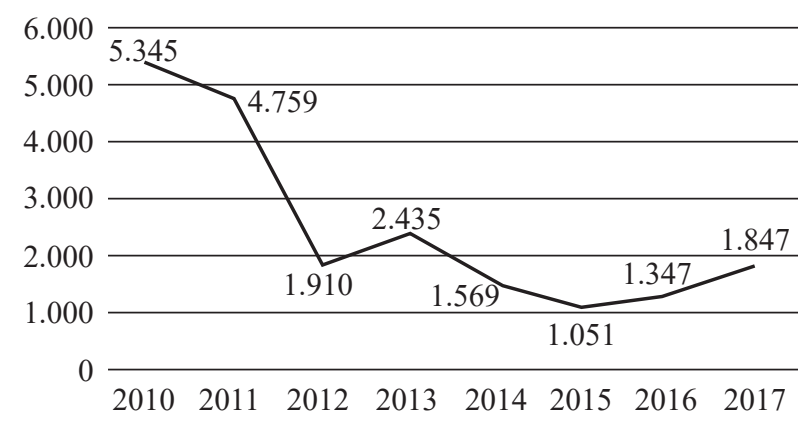

Sumber : www.idx.co.id (Data diolah)

Gambar 1. Grafik Rata-Rata Harga Saham Sektor Pertambangan yang Terdaftar di BEI Periode 2010-2017 (Dalam Rp)
Business and Social Science, 5(8), 230-238.

Pambayun, G. A., \& Sulasmiyati, S. 2017. Pengaruh Kepemilikan Manajerial, Debt To Equity Ratio Dan Assets Growth Terhadap Dividen Payout Ratio (Studi Pada Perusahaan LQ-45 Yang Terdaftar Di Bursa Efek Indonesia Periode 2012-2015). Jurnal Administrasi Bisnis, 51(2), 118-125. administrasibisnis.studentjournal.ub.ac.id

Rafique, M. 2012. Factors Affecting Dividend Payout : Evidence From Listed Non-Financial Firms of Karachi Stock Exchange (C) Society for Business and Management Dynamics, 1(11), 76-92.

Rahayu, D., \& Rusliati, E. 2019. Kepemilikan Institusional, Kepemilikan Manajerial, dan Ukuran Perusahaan Terhadap Kebijakan Dividen. Jurnal Riset Akuntansi Kontemporer, 11(1), 41-47.

Rehman, A., \& Takumi, H. 2012. Determinants of Dividend Payout Ratio: Evidence From Karachi Stock Exchange (KSE). Journal of Contemporary Issues in Business Research, 1(1), 20-27.

Suhadak dan Darmawan, A. 2011. Pemikiran Kebijakan Manajemen Keuangan. CV. Okani Bukaka.

Supriyanah, \& Ghoniyah, N. 2015. Kebijakan Pendanaan, Insider Ownership dan Firm Size terhadap Nilai Perusahaan yang Listed di Bursa Efek Indonesia (BEI) tahun 2010-2013. Jurnal Ekonomi Dan Bisnis, 16(1), 68-79.

Sutrisno. 2012. Manajemen Keuangan Teori, Konsep, dan Aplikasi. Ekonisia.

Yee, T. C. 2017. Dividend Pay-out Policy and Firm Performance. Journal of Arts \& Social Sciences, 1(1), 42-52.

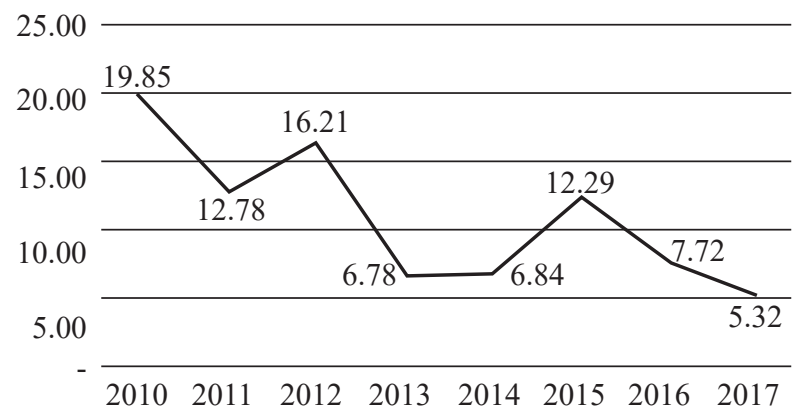

Sumber : www.idx.co.id (Data diolah)

Gambar 2. Rata-rata Free Cash Flow Perusahaan Sektor Industri Pertambangan yang Terdaftar di BEI Periode 2010-2017 

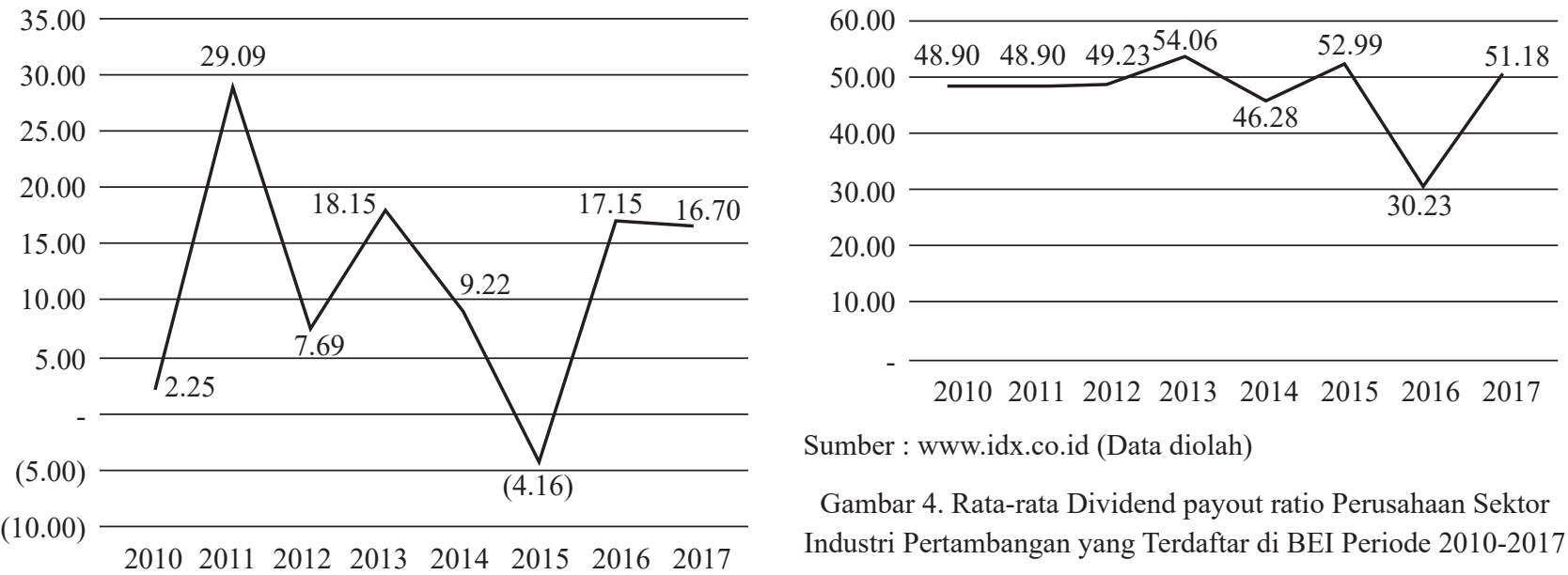

Sumber : www.idx.co.id (Data diolah)

Gambar 4. Rata-rata Dividend payout ratio Perusahaan Sektor Industri Pertambangan yang Terdaftar di BEI Periode 2010-2017

Sumber : www.idx.co.id (Data diolah)

Gambar 3. Rata-rata Pertumbuhan Perusahaan Sektor Industri

Pertambangan yang Terdaftar di BEI Periode 2010-2017

Tabel 1. Operasionalisasi Variabel

\begin{tabular}{l} 
Variabel \\
\hline Insider Ownership $\left(\mathrm{X}_{1}\right)$ \\
Kepemilikan manajerial diperoleh dari jumlah saham yang \\
dimiliki oleh direksi dan manajer \\
dibagi dengan jumlah saham yang beredar. \\
(Gitman, Lawrence J. and Zutter, 2015)
\end{tabular}

Free Cash Flow/Arus Kas Bebas $\left(\mathrm{X}_{2}\right)$

Arus kas bebas adalah arus kas yang benar-benar tersedia untuk dibayarkan kepada investor (pemegang saham dan pemilik utang) setelah perusahaan melakukan investasi dalam aset tetap, produk baru, dan modal kerja yang dibutuhkan untuk mempertahankan operasi yang sedang berjalan.

(Brigham \& Houston, 2019)

Growth/Pertumbuhan Perusahaan $\left(\mathrm{X}_{3}\right)$

Pertumbuhan adalah perubahan (peningkatan atau penurunan) total aset yang dimiliki oleh perusahaan.

(Brigham \& Houston, 2019)

\section{Dividend Payout Ratio(Y)}

Dividend payout ratio menunjukkan presentase dari setiap dollar yang dihasilkan oleh sebuah perusahaan yang didistribusikan kepada pemilik dalam bentuk tunai. Dividend payout ratio dihitung dengan membagi dividen kas per saham dengan laba per saham.

(Gitman, Lawrence J. and Zutter, 2015)
- Total Aktiva

Growth $=\frac{\text { TA(t) TA(t-1) }}{\text { Total Aktiva(t-1) }} \times 100 \%$

Rasio

(Brigham \& Houston, 2019)

a. Dividend per share (dividen per saham).

b. Earning per share (laba per saham).

$$
\mathrm{DPR}=\frac{\mathrm{DPS}}{\mathrm{EPS}} \times 100 \%
$$

Rasio

(Gitman, Lawrence J. and Zutter, 2015)

\begin{tabular}{cr} 
Pengukuran & Skala \\
\hline MOWN $=\frac{\sum \text { Saham Manajerial }}{\Sigma \text { Saham Beredar }} \times 100 \%$ & Rasio
\end{tabular}

(Gitman, Lawrence J. and Zutter, 2015)

$$
\mathrm{FCF}=\frac{\text { AKOB }- \text { AKIB }}{\text { Total Aktiva }} \times 100 \%
$$

Rasio

(Brigham \& Houston, 2019) 
14 Jurnal Riset Akuntansi Kontemporer

Yessri Meiliyawati

Volume 12, No. 1, April 2020

Ellen Rusliati

Tabel 2. Analisis Regresi Data Panel

Dependent Variable: DPR

Tabel 3. Pengujian Hipotesis Common Effect

Method: Panel Least Squares

Date: 07/14/19 Time: 16:03

Sample: 20102017

Periods included: 8

Cross-sections included: 4

Total panel (balanced) observations: 32

\begin{tabular}{ccccc}
\hline Variable & Coefficient & Std. Error & t-Statistic & Prob. \\
\hline C & 49.04809 & 5.033155 & 9.744998 & 0.0000 \\
KM & 49.40610 & 8.209658 & 6.018046 & 0.0000 \\
FCF & -0.818331 & 0.285129 & -2.870038 & 0.0077 \\
GROWTH & -0.286263 & 0.126478 & -2.263334 & 0.0316 \\
\hline Sumber $:$ Hasil
\end{tabular}

\begin{tabular}{llll}
\hline R-squared & 0.637929 & Mean dependent var & 48.62469 \\
Adj. R-squared & 0.599135 & S.D. dependent var & 19.34696 \\
S.E. of regression & 12.24931 & Akaike info criterion & 7.965285 \\
Sum squared resid & 4201.276 & Schwarz criterion & 8.148502 \\
Log likelihood & -123.4446 & Hannan-Quinn criter. & 8.026016 \\
F-statistic & 16.44429 & Durbin-Watson stat & 2.711425 \\
Prob(F-statistic) & 0.000002 & & \\
\hline
\end{tabular}

Sumber: Hasil Olah Data Eviews 9

Sumber : Hasil Olah Data Eviews 9 